Article

\title{
Adventure Races in Brazil: Do Stakeholders Take Conservation into Consideration?
}

\author{
Carolina Bartoletti *D, Teresa Cristina Magro-Lindenkamp and Gabriel Adrián Sarriés \\ Applied Ecology Department, University of São Paulo, Piracicaba 13416-000, Brazil \\ * Correspondence: carolina.bartoletti@usp.br
}

Received: 13 May 2019; Accepted: 25 June 2019; Published: 3 July 2019

\begin{abstract}
This case study used exploratory and descriptive research to look into how stakeholders involved in the organization and practice of adventure races in Brazil perceive impacts related to this outdoor activity. Additionally, questions were posed about whether such impacts have been taken into consideration when planning these sporting events. Finally, the research aimed to understand why racers and adventure race organizers choose a certain time of year and venue to partake and organize a race: whether for more logistical purposes or also considering conservation. Online surveys were set up to target adventure race organizers, racers, and national park managers. Overall, there seems to be very little knowledge among racers and race organizers about social and environmental impacts associated with adventure races. This has led to the organization of events with very few or no specific concerns to the environment. Moreover, racers and adventure race organizers seem to perceive certain ecological issues-i.e., erosion—as challenges to the sport and not a problem to be addressed or avoided. National park managers were the group surveyed with more knowledge about the negative impacts adventure races might have on the environment.
\end{abstract}

Keywords: protected areas; adventure races; conservation; impacts

\section{Introduction}

The use of natural areas for recreation, sports and physical activities is of increasing importance to a range of professionals from park managers to public health managers. In the United States, recent national initiatives have called upon federal agencies to aid the promotion of healthier lifestyles. In response, the National Park Service has developed strategies to increase access and opportunities for physical activities in national parks [1].

In Brazil, there are still no governmental initiatives to stimulate outdoor recreation. However, there has been an increase in the use of protected areas for a variety of sporting events. Adventure races are one such example. These races began to be organized in Brazil in 1998 with a single annual event named Expedição Mata Atlântica (Atlantic Forest Expedition), and in the past two decades the country has hosted two adventure race world championships (in 2008 and 2015, respectively) besides numerous other smaller events each year [2].

Adventure races are extenuous competitions that may endure for hours or days. Protected areas, such as national parks, became common settings for races as the sport is considered part of a "greening" or "adventuring" trend in outdoor recreation in response to an increasing demand for natural spaces for leisure [3]. Arnegard and Sandell [4] described the activity as a "sportification" of outdoor recreation in protected areas.

Such "sportification" raises concerns that the events may not be adequately planned with care for the environment, only for what is best for the organizing parties. One previous study conducted in Brazil showed that often private interests from sponsoring and organizing companies overlap environmental conservation in the organization of adventure races [5]. 
The sports that compose an adventure race are directly linked to nature. They may vary from competition to competition, but usually include mountain biking, hiking, canoeing, rafting, and rappelling. Depending on the competition and venue, open water swimming, horseback riding and other sports may be added or substitute for the more traditional ones [6,7].

The literature shows that outdoor sports have the potential to cause a range of social and environmental impacts in natural areas. Biophysical effects may include soil erosion, soil compaction, addition of nutrients and microbes from human waste, creation of secondary trails, and spread of alien seeds $[6,8]$. Social impacts may include noise pollution, conflicts of use among different natural area visitors, and safety issues such as the possibility of collisions and injuries [9].

Thus, the main aim of this research was to explore how stakeholders in the organization and practice of adventure races in Brazil perceive potential social and environmental impacts, such as the above mentioned, and whether they take them into consideration when planning these sporting events.

Secondly, the research pursued an understanding of what motivates adventure racers and organizers to choose a specific location and date to compete and organize an adventure race, respectively: factors more related to nature conservation or to logistics?

Ever since adventure races were introduced in Brazil in 1998, there has not been an emphasis on research oriented to understanding how these races are being organized and how they affect protected areas, and information of this sort is crucial for the proper management of these areas.

\section{Materials and Methods}

Studies about the relationship between protected area managers and interest groups, including local communities and visitors, are best performed from the perspective of case studies, once each context offers singularities $[10,11]$. This is why it was chosen as the methodological framework for this research. Although the study did not focus on one single event or one single site, it did focus on the relationship among national park managers, adventure racers and race organizers. It did not focus on the relationship between adventure racers and organizers and other protected area managers, such as state parks managers, as national parks tend to be more attractive for big events such as the adventure race world championships that have been organized in Brazil.

The data presented here were collected through online surveys during a two-month period. Surveys are extensively used by Manning [12] in his works about outdoor recreation and park management, and the choice for online submission stemmed from the fact that in our research it was found that in 11 out of the 26 Brazilian states adventure races take place. Therefore, it would be impracticable to conduct the surveys in person.

Since it was more convenient to approach stakeholders in different states using the internet, three questionnaires were designed to target a specific adventure race stakeholder: race organizers, athletes, and national park managers.

For the making of the online questionnaires a Likert-type scale was used as a tool to evaluate factors that could influence the choice of adventure race organizers and racers of venues and times of the year to organize/participate in an adventure race [13]. Goonan et al. [14] have used a similar questionnaire structure based on Likert Scale questions to evaluate the importance of factors related to trail quality at Acadia National Park in the United States.

Additionally, there were open ended and binomial questions to address the perception of impacts associated with adventure races. The latter were analysed with the Binomial Test which applies to questions and situations that yield results in a binomial distribution, such as odd or even situations and yes or no questions. For this test, when $p$-value is less than $5 \%(p<0.05)$ there is statistical difference between results [15]. 
Selection and Approach to Subjects

The Brazilian Adventure Race Confederation (CBCA—Confederação Brasileira de Corrida de Aventura) was consulted about the possibility of disclosing a list of companies that organize adventure races in Brazil. As the official agency for the sport it was expected that it would hold a list for reference.

However, it was found that many companies were not enlisted with the confederation and that, in fact, only nine companies were registered within it. Due to this fact, a second consult was conducted online via Google ${ }^{\mathrm{TM}}$ in order to search for more companies. A similar approach was conducted by Rossi, Pickering and Byrne [9] when researching horse ride companies for a Queensland Government report on trail use in Australia.

This online search used as filter the key words "adventure race companies" and twenty-six other companies were found mounting up to thirty-five in total.

Athletes were approached by social media for there was no other specific channel to contact them without a race organizer providing a contact list. The Brazilian Adventure Race Confederation stated it had no contact list of athletes, neither professional nor amateur.

Three groups were found on Facebook for Brazilian adventure racers:

- Corredores de Aventura-https://www.facebook.com/groups/174860835861704/

- Corrida de Aventura-https://www.facebook.com/groups/322669764444488/

- Brou Aventuras-https://www.facebook.com/groups/145105445572475/

Although the use of virtual tools as Google ${ }^{\mathrm{TM}}$ and Facebook might be held inadequate for scientific purposes, Manning and Freimund [16] already pointed out to the diversification of research methods due to technological innovation as the ever-increasing use of personal computers and internet.

Finally, national park managers were contacted through a virtual database for protected areas in Brazil named National Cadastre of Protected Areas (CNUC - Cadastro Nacional de Unidades de Conservação, in Portuguese) wherein telephone and e-mail information were available.

Race organizers and park managers were therefore contacted firstly via e-mail and then directly by phone. All were given a link to the research webpage (http://www.esalq.usp.br/corridadeaventura/) wherein their answers to the survey would be submitted. If they agreed to participate in the survey, then a user ID and password were sent to race organizers and park managers via e-mail. Athletes had open access to their questionnaire as the invitation was not personal and sent through social media along with the webpage link.

Submissions were anonymous, as required by the ethics' committee at University of São Paulo. Answers were segmented by stakeholder group when they inserted the ID and password given, or in the case of athletes, when they selected "open access" to the questionnaire.

An informed consent agreement was on the front page of the website. Only upon agreement could the subject submit any answers as required by the ethics' committee at University of São Paulo.

\section{Results and Discussion}

\subsection{Factors of Influence on Dates for Adventure Races}

Regarding factors that could influence the choice of an athlete to partake in an adventure race on a specific time of year, a few factors were suggested for evaluation, as shown in Table 1. Some of the factors bore a direct relationship to conservation, but in the questionnaire, they were all randomized in order not to suggest or interfere with the answers.

For the sample of athletes who answered the questionnaire, the breeding season of endangered species coinciding with the time of a race was chosen as the most important factor to consider in order to avoid events that would take place in areas where endangered species would be reproducing. Second in importance was the weather and the challenge it provides during the race.

On the contrary, as the least important factors to influence the choice of a time of year to race was whether it was high or low touristic season in the venue of the race. 
Table 1. Factors that might influence the choice of a time of year to partake in an adventure race.

\begin{tabular}{cc}
\hline \multicolumn{1}{c}{ Logistics-Related Factors } & Conservation-Related Factors \\
\hline Training calendar (optimal period for competition) & Rain and possibility of soil erosion \\
\hline Weather and the comfort it provides during the race & $\begin{array}{c}\text { Breeding season of endangered species } \\
\text { during the time of the race }\end{array}$ \\
\hline Weather and the challenge it imposes during the race & \\
\hline Touristic use of the area (to be high season during the race) & \\
\hline Touristic use of the area (to be low season during the race) & \\
\hline
\end{tabular}

The same seven factors of influence on the choice of dates-this time to organize an adventure race-were put under the evaluation of race organizers. The main difference was that the factor training calendar was replaced by event calendar to represent the adventure races' event schedule so that there would be no date coincidences among races.

This was exactly the factor of most importance to organizers followed by the breeding season of endangered species. It shows that, for them, it is imperative to consider other adventure racing events in order to avoid promoting two races at the same time, but also that it is important to consider the time of reproduction of endangered species to avoid organizing a race when and where they procreate.

As it was for the sample of athletes, whether it would be high or low touristic season in the time of their race was ranked least among the factors for these adventure race organizers.

The fact that neither racers nor organizers made a great distinction between it being high or low touristic season when an adventure race happens may be good news for park managers as it makes it possible to suggest that adventure races take place during the low touristic season in order to decrease the possibility of social conflicts with other visitors during the high season.

\subsection{Factors of Influence on Venues for Adventure Races}

When it came to the evaluation of factors that could influence the choice of venues for adventure races athletes and organizers were asked to evaluate the following (Table 2):

Table 2. Factors of influence in the choice of a venue for an adventure race.

\begin{tabular}{cc}
\hline Logistics-Related Factors & Conservation-Related Factors \\
\hline Ease to access race location & Vegetation and resilience to trampling \\
\hline Ease to access by rescue parties & Soil and possibility of erosion in the venue \\
\hline $\begin{array}{c}\text { Comfort (proximity to hotels and restaurants) } \\
\text { Athlete security (proximity to hospitals) }\end{array}$ & The fact that the venue is a protected area \\
\hline $\begin{array}{c}\text { Risk (i.e., exposure to endemic diseases and fauna } \\
\text { that represents a menace to men) }\end{array}$ & Landscape beauty \\
\hline & Remote and wild quality of the natural area \\
\hline
\end{tabular}

Athletes ranked "terrain and the challenge it provides for the race" first and they ranked "soil and possibility of erosion in the venue" least. This finding suggests that their perception is that erosion is not a concern, not something to worry about nor consider when choosing a place to race because in fact, for them, the rougher the terrain the better.

Faria et al. [17] found that park visitors who practice adventure sports often have preferences regarding spatial features of the place the sport is practiced in. The authors found that one of these preferred features is a rough terrain. 
In this research it was also found that $89.5 \%$ of the athletes' sampled perceived the terrain and the challenge it provides either as important or even indispensable for the venue of an adventure race.

The management concern this fact raises is that for many adventure racers erosion is not perceived as an ecological problem rather as challenge provided by a rough terrain for their sport [18].

From the perspective of conservation and park management, this finding indicates the need for more targeted environmental education to inform adventure racers and other adventure sports enthusiasts that although a rough terrain provides challenge for their sport, erosion is an environmental issue and challenge may come from other features such as natural obstacles, sandy paths, and single tracks.

In turn, organizers ranked "landscape beauty" first as the most important feature of a place where to organize an adventure race. However, they too ranked "soil and possibility of erosion" least, which once more calls for attention in how to communicate with these stakeholders about impacts related to their recreational activity.

\subsection{Social and Environmental Impacts on the Planning of Adventure Races}

Besides the evaluation of important factors related to the organization of adventure races, organizers were also asked if the planning and rules for their events included items linked to their potential impacts in natural areas and how to prevent them.

Only $12.5 \%$ mentioned the existence of such items on the planning of their events and a slightly higher percentage, $37.5 \%$, mentioned rules for the races that contained items for the prevention or punishment of acts harmful to the environment.

If the organizer answered that the adventure race he planned had items concerned with conservation in the project or rules, they were asked to attach documents that proved the event had in fact a planning or at least rules concerned with potential social and environmental impacts.

However, only one organizer attached the rule statement of his event which can be explained either by the fact that none of the others actually had documents to prove their races were concerned with the environment or because they found these documents, specially the race project, to be confidential.

The one rule statement provided claimed that teams which damaged the environment would be declassified from the race. However, the statement was not clear as to what would be considered damage to the environment.

\subsection{Perceptions of the Potential for Adventure Races to Cause Impacts}

Finally, all three stakeholder groups were questioned if they perceived adventure races to cause social and environmental impacts. This yes/no question yielded the graph below (Figure 1) which shows that the majority of racers and adventure race organizers perceive that the sport has positive impacts, but only a few believe it can too cause negative ones.

National park managers were the group with the most balanced opinion and knowledge about the potential for adventure races to cause impacts. They claimed adventure races can cause positive $(96.7 \%)$ as well as negative impacts in the environment and community $(93.3 \%)$.

Among statements provided further explaining their professional views, Park Manager 1 said:

"Adventure races and other sporting events have potential to cause negative impacts to the biodiversity and geological features of a protected area. Thus, it is important and necessary to compare these negative impacts to the positive ones in order to decide whether the activity is suitable or not."

National Park Manager 2 stated:

"Sporting events in protected areas may cause profound social and economic impacts on local and traditional communities changing their social profiles and traditional economical activities. Of course, negative impacts as these are also related to other recreational and touristic activities, but as such adventure races can potentiate them." 
As for positive impacts related to the events, Park Manager 3 said:

"When events are well planned and managed, sporting and recreational activities can bring closer society and protected areas with mutual benefits. The stimulus to visitation not only by the activity itself but through a broader advertising of the natural area can strengthen tourism in protected areas and aid the economic development of local communities, as well as bring an alternative financial income for the maintenance of the protected area.

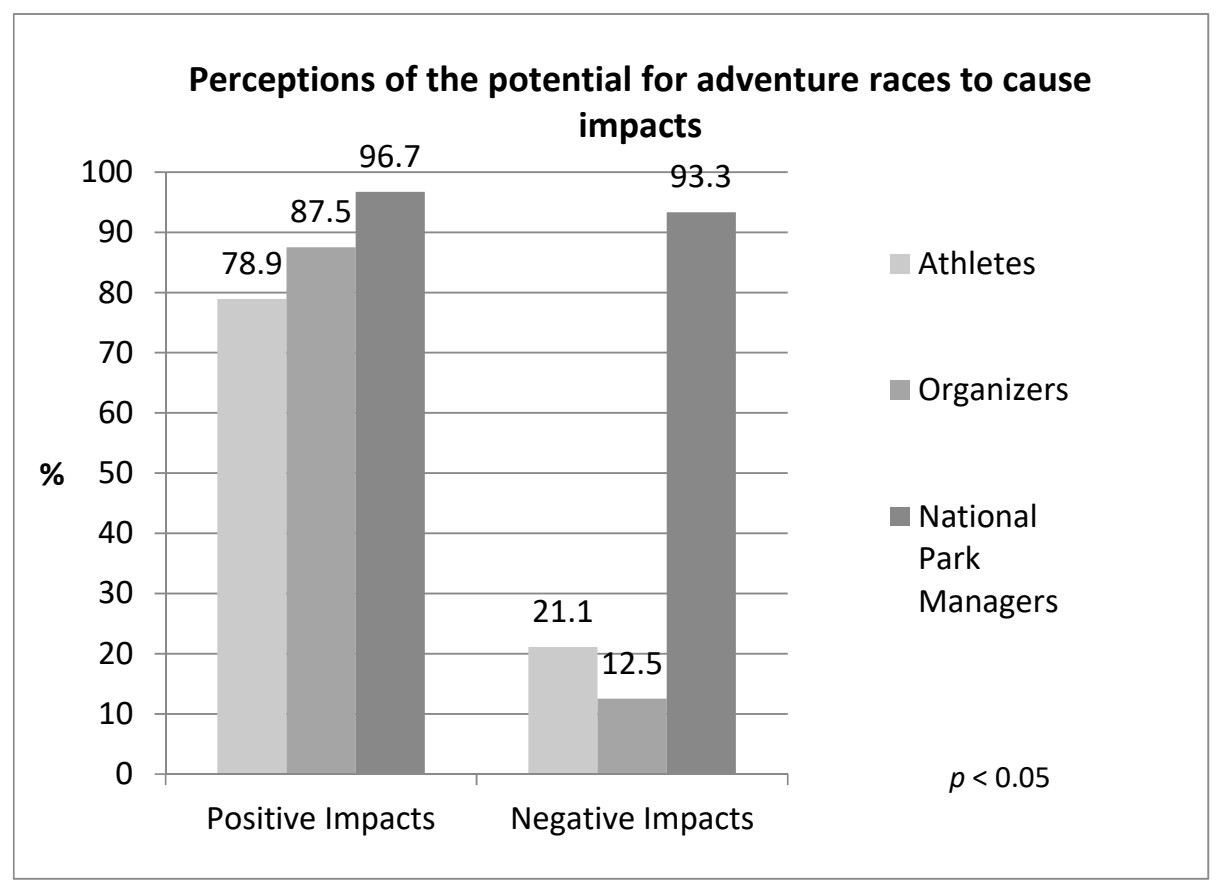

Figure 1. Perceptions of social and environmental impacts among stakeholders.

\section{Limitations to the Research}

Despite extensive advertising on social media and personal invitations via e-mail and phone for subjects to participate in this research, a much smaller sample than expected did answer the questionnaires, as shown on Table 3.

Table 3. Percentage of respondents.

\begin{tabular}{ccc}
\hline Population & Respondent Sample & Percentage of Total \\
\hline Athletes & 19 subjects & $*$ \\
National Park Managers & 35 subjects $/ 67$ & $52.2 \%$ \\
Adventure Races' Organizers & 8 subjects $/ 35$ & $22.8 \%$ \\
TOTAL & 62 subjects & $100 \%$ \\
\hline
\end{tabular}

* unknown total population.

National park managers were the group with the higher participation rate. Over $50 \%$ of the 67 managers in the country replied to the survey. It was hypothesized that athletes and adventure race organizers might still perceive research of this kind as a threat to their activity and so did not participate.

\section{Conclusions}

In comparison to other countries, such as New Zealand and Australia, where adventure races began in the 1980s [19] the history of adventure races in Brazil is more recent-beginning only two decades ago. Thus, it was difficult to find information on the potential impacts of the activity. 
Most works on the theme stem from foreign literature $[3,4,6,7,19]$ while a few have been conducted in Brazil [5,18].

This may explain why most adventure race organizers and racers disclosed they did not perceive the sport to be able to cause negative impacts on nature: if it is scarcely researched, information is not available for stakeholders. Thus, it sheds a light on the need for more local research on the activity and for more targeted environmental education and dialogue with stakeholders, specially racers and race organizers.

Similarly, Newsome and Lacroix [20] have called for an increased dialogue in connection with the trend towards the "sportification" [4] of protected areas, and in relation to the dilemma faced by many protected area managers as to whether to approve or decline an activity or event in a particular protected area.

Newsome [7] also stated the urgent need for policy guidelines that can assist managers to make the best environmental decisions when it comes to adventure races in protected areas.

From this initiatory and exploratory research in Brazil, it was possible to observe that conservation is not yet a main concern when athletes and race organizers choose a venue and date to organize or participate in an adventure race. Other factors seem to bear more importance to organizers, such as logistics to avoid organizing two races at the same time. Furthermore, the projects and rules for races rarely included penalties for participants who harm the environment. When they do, it is unclear what is considered harm or damage to the environment.

In this sense, guidelines as suggested by Newsome [7] would aid not only park managers, but also race organizers to come up with clearer projects in which conservation is a key aspect.

Another final consideration of this work is that if adventure racers and organizers do not yet take into consideration conservation when planning their sporting events or choosing a place to compete, and this may reflect that they do not see protected areas as places for conservation, rather as places for the sheer practice of sports, much like a tennis court or soccer field.

This would have detrimental effects for the maintenance and public support for protected areas as they lose what Newsome [7] calls "the conservation value" of such areas.

It is worth noting that this data cannot serve as a generalization as more subjects would statistically be needed for that. However, the research shed a light over the organization of adventure races in Brazil and over how more people still need to be encouraged to think about issues associated with conservation in protected areas used for recreational purposes.

Author Contributions: Conceptualization, C.B.; Methodology, G.A.S. and T.C.M.-L.; Software, G.A.S.; Formal analysis, G.A.S.; Investigation, C.B.; Data curation, G.A.S.; Supervision, T.C.M.-L.; Writing-original draft preparation, C.B.; Writing-review and editing, T.C.M.-L.; Funding acquisition, C.B.

Funding: This research was funded by the Coordenação de Aperfeiçoamento de Pessoal de Nível Superior-Brasil (CAPES)-Finance Code 001.

Conflicts of Interest: The authors declare no conflict of interest.

\section{References}

1. Walden-Schreiner, C.; Leung, Y.-F.; Floyd, M.F. Incorporating physical activity measures into environmental monitoring of National Parks: an example from Yosemite. J. Phys. Act. Health 2014, 11, 1284-1290. [CrossRef] [PubMed]

2. Adventure Race World Championship. Available online: http://arwcpantanal.com/pt-br/a-corrida/equipes (accessed on 20 December 2015).

3. Pociello, C. Le future comm une nouvelle forme d'enjeu'. In Sport et Pouvoirs au XXe Siecle; Clement, J.P., Defrance, J., Pociello, C., Eds.; Presses Universitaires de Grenoble: Grenoble, France, 1994; pp. 118-122.

4. Arnegard, J.; Sandell, K. Outdoor recreation in times of change. In Proceedings of the 6th International Conference on Monitoring and Management of Visitors in Recreational and Protected Areas, Stockholm, Sweden, 21-24 August 2012. 
5. Alves, A.P.; Almeida Júnior, A.R. Corrida de Aventura: entre o Esporte e o Marketing. In Proceedings of the II Colóquio Binacional Brasil-México de Comunicação, São Paulo, Brasil, 1-3 April 2009.

6. Newsome, D.; Lacroix, C.; Pickering, C.M. Adventure racing events in Australia: Context, assessment and implications for protected area management. Aust. Geogr. 2011, 42, 403-418. [CrossRef]

7. Newsome, D. Appropriate policy development and research needs in response to adventure racing in protected areas. Biol. Conserv. 2014, 171, 259-269. [CrossRef]

8. Pickering, C.M.; Hill, W.; Newsome, D.; Leung, Y.-F. Comparing hiking, mountain biking and horse-riding impacts on vegetation and soils in Australia and the United States of America. J. Environ. Manag. 2010, 91, 551-562. [CrossRef] [PubMed]

9. Rossi, S.D.; Pickering, C.M.; Byrne, J. Perceptions of Stakeholder Organisations: Assessing the Social Impacts of the South East Queensland Horse Riding Trail Network, 1st ed.; Griffith University: Brisbane, Australia, 2013; pp. 24-28.

10. Yin, R.K. Case Study Research: Design and Methods, 4th ed.; Sage: Thousand Oaks, CA, USA, 2009.

11. Flyvbjerg, B. Case study. In The Sage Handbook of Qualitative Research, 4th ed.; Denzin, N.K., Lincoln, Y.S., Eds.; Sage: Thousand Oaks, CA, USA, 2011; pp. 301-316.

12. Manning, R.E. Parks and People, 1st ed.; University of Vermont Press: Burlington, VT, USA, 2009; pp. 90-94.

13. Likert, R. A Technique for the Measurement of Attitudes. Arch. Psychol. 1932, 140, 1-55.

14. Goonan, K.; Manning, R.E.; Valliere, W. Research to guide trail management at Acadia National Park. Gen. Tech. Rep. 2009, 42, 266-274.

15. Silva, O.; da Câmara, F.G. Estatística Não-Paramétrica: Teste de Hipóteses e Medidas de Associação, 1st ed.; Universidade dos Açores: Ponta Delgada, Portugal, 2001.

16. Manning, R.E.; Freimund, W. Use of visual research methods to measure standards of quality for Parks and Outdoor Recreation. J. Leis. Res. 2004, 36, 557-579. [CrossRef]

17. Faria, A.C.V.; Castro, C.A.; das Dores Dezidério, M.; da Silva Ferreira, M.; da Silva Guedes, W. Turismo e impactos ambientais: um estudo sobre a trilha e a Cachoeira dos Macacos-Distrito São Sebastião das Águas Claras, Nova Lima/MG. Cad. de Geografia 2010, 20, 1-7.

18. Bartoletti, C.; Magro, T.C.; Sarries, G.A. Stakeholders' perceptions towards factors of influence on the choice of places for Adventure Races. In Proceedings of the 9th International Conference on Monitoring and Management of Visitors in Recreational and Protected Areas, Bordeaux, France, 29-31 August 2018.

19. Kay, J.; Laberge, S. Mapping the field of 'AR': Adventure racing and Bourdieu's concept of Field. Sociol. Sport J. 2002, 19, 25-46. [CrossRef]

20. Newsome, D.; Lacroix, C. Changing recreational emphasis and the loss of 'natural experiences' in protected areas: An issue that deserves consideration, dialogue and investigation. J. Tour. Leisure Stud. 2011, 17, 315-333. 